\title{
Empowerment of Village Health Worker to Become Assistance to Mother Groups in Prevention of ISPA in Toddlers by Using Complementary Therapy
}

\author{
Lufthiani ${ }^{1 *},{ }^{1}$ Evi Karota, ${ }^{3}$ Cholina Trisa Siregar ${ }^{2}$ \\ ${ }^{1}$ Department of Mental and Community Nursing, Faculty of Nursing, University Sumatera \\ Utara \\ ${ }^{2}$ Department of Basic Nursing and Medical Surgery Faculty of Nursing, University Sumatera \\ Utara \\ Email*: lufthiani@usu.ac.id
}

\begin{abstract}
ISPA is a respiratory disorder that causes children to tend to be lethargic, fussy, and lack of appetite, thus reducing the child's immunity which affects other health problems. The use of Complementary Therapies can help to reduce the impact of disease incidence, especially ISPA in toddlers at home as an alternative therapy for self-medication for families. It is hoped that the involvement of village health worker in the mother group in the community is directly involved in implementing the program to create and increase the ability to live healthy in a sustainable manner. The method of implementing community service activities is carried out by providing education, training and mentoring to 41 people consisting of village health worker and mother groups. The implementation of activities for the mothers group began with distributing pre-test questionnaires, then continued with providing health education about complementary therapies, herbal therapy simulations and toddler massage training to village health worker and mother groups, the activities were evaluated by providing posttest sheets. The results of the implementation of community service activities after health education and training activities obtained good knowledge about complementary therapies $(75.6 \%)$ and sufficient knowledge (24.4\%), paired t-test results before and after health education and the training obtained $\mathrm{p}$ value 0.005 . It is hoped that village health worker can become activists and health promoters for mothers in an effort to prevent health problems by using complementary therapies.
\end{abstract}

Keyword: Empowerment of village health worker, complementary therapy, ISPA

Abstrak

ISPA merupakan gangguan pernafasan yang menyebabkan anak cenderung menjadi lesu, rewel, dan kurang nafsu makan sehingga menurunkan imun anak yang berpengaruh pada masalah kesehatan lainnya. Penggunaan Terapi Komplementer dapat membantu untuk mengurangi dampak kejadian penyakit khususnya ISPA pada Balita di rumah sebagai terapi alternatif pengobatan mandiri untuk keluarga. Keterlibatan Kader Kesehatan pada kelompok Ibu di masyarakat diharapkan langsung dalam pelaksanaan program untuk menciptakan, meningkatkan kemampuan hidup sehat pada secara berkesinambungan. Metode pelaksanaan kegiatan pengabdian kepada masyarakat dilakukan dengan memberikan edukasi, pelatihan dan pendampingan kepada 41 orang yang terdiri dari kader dan kelompok Ibu. Pelaksanaan kegiatan pada kelompok Ibu diawali dengan membagikan lembar kuesioner pre tes, kemudian dilanjutkan dengan memberikan penyuluhan kesehatan tentang terapi komplementer, simulasi terapi herbal dan pelatihan pijat Balita kepada Kader dan kelompok Ibu, kegiatan dievaluasi dengan memberikan lembar Post tes. Hasil Pelaksanaan kegiatan pengabdian kepada masyarakat setelah dilakukan kegiatan penyuluhan kesehatan dan pelatihan diperoleh pengetahuan Baik tentang terapi komplementer $(75,6 \%)$ dan pengetahuan cukup sebesar (24,4\%), Hasil uji paired t-test pada sebelum dan sesudah diberikan pendidikan kesehatan dan pelatihan diperoleh nilai p 0.005. Diharapkan kader Kesehatan dapat menjadi penggerak dan promotor kesehatan bagi kelompok Ibu dalam upaya pencegahan masalah kesehatan dengan menggunakan Terapi Komplementer.

Kata Kunci: Pemberdayaan Kader Kesehatan, Terapi Komplementer, ISPA 


\section{PENDAHULUAN}

Kejadian Infeksi Saluran Pernafasan Akut (ISPA) masih menjadi salah satu masalah kesehatan masyarakat yang penting untuk diperhatikan, karena merupakan penyakit akut yang dapat menyebabkan kematian pada balita di berbagai negara berkembang termasuk Indonesia. Berdasarkan data Kemenkes tahun 2015, cakupan penemuan ISPA pada Balita tahun 2014 berkisar antara 20-30 \%, sedangkan pada tahun 2015 terjadi peningkatan menjadi 63,45\%. Menurut Riskesdas (2013) ISPA pada balita dipengaruhi oleh beberapa faktor yaitu gizi yang kurang, status imunisasi, lingkungan tempat tinggal, polusi udara di rumah, orang yang perokokdan keadaan rumah yang tidak sehat (Jayatmi, I., \& Imaniyah, E. (2019). Balita merupakan individu yang berada pada fase tumbuh kembang yang penting untuk diperhatikan. Sistem imun yang belum sempurna menyebabkan balita rentan terkena infeksi ISPA. Pencegahan ISPA sangat erat kaitannya dengan sistem kekebalan tubuh yang dimiliki seseorang. Kerentanan ISPA yang terjadi pada balita kasus ini menunjukkan prevalensi yang tinggi terjadi di Dunia dibandingkan dengan penyakit lain. Orang tua memiliki peran yang sangat penting pada masa pertumbuhan dan perkembangan anak, dan sekaligus berperan dalam upaya pencegahan dan pemeliharaan kesehatan keluarga. Setiap keluarga melakukan penanganan pencegahan penyakit di rumah dengan cara yang berbeda-beda. Terkadang banyak orang tua menganggap masalah ISPA ini menjadi hal yang diabaikan sehingga sering kali keterlambatan dalam pencarian pelayanan kesehatan menjadi penyebab kematian pada ISPA (Rahman, Prabamurti \& Riyanti, E. (2016). Faktor-faktor yang dapat mempengaruhi orang tua dalam perilaku pencarian pelayanan kesehatan antara lain status sosial ekonomi, pendidikan, persepsi orang tua tentang penyakit, jumlah anggota keluarga, dan kemampuan keluarga dalam memahami pentingnya upaya pencegahan penyakit. Salah satu upaya pengobatan yang dapat dilakukan untuk mengatasi ISPA selain menggunakan medical therapy yaitu dengan memanfaatkan Terapi Komplementer yang dapat dijadikan sebagai pengobatan alternative untuk pencegahan penyakit. Di Indonesia sendiri, terapi komplementer telah sangat popular di kalangan masyarakat luas. Berbagai jenis terapi komplementer yang dapat digunakan untuk membantu pencegahan maupun pemulihan dari penyakit ISPA. Maka dari itu pemanfaatan terapi komplementer ini perlu diinformasikan dan disosialisasikan kepada masyarakat.

Kader kesehatan merupakan salah satu bagian dalam upaya pengembangan masyarakat yang bertujuan membantu masyarakat mengubah sikapnya terhadap perilaku sehat. Kader kesehatan menjadikan masyarakat sebagai subyek kegiatan yang menjadi sasaran dalam kegiatan. Melalui pemberdayaan peran kader kesehatan dalam upaya pencegahan dan pemeliharaan kesehatan di masyarakat diharapkan menjadi optimal. Oleh sebab itu pengetahuan dan kemampuan komunikasi dan motivasi yang nantinya dapat dijalankan oleh kader kesehatan kepada masyarakat khususnya sasaran terdekat kader yaitu kelompok Ibu diharapkan peningkatan yang lebih memadai. Sehingga kader dapat menjadi perpanjangan tangan dalam informasi kesehatan maupun pemeliharaan kesehatan petugas kesehatan kepada masyarakat. Secara teknis tugas Kader Kesehatan sebagai tata laksana pembangunan kesehatan di masyarakat dalam pelaksanaan kegiatan Posyandu. Beberapa peran penting yang harus dilakukan oleh Kader Kesehatan seperti melakukan penyuluhan kesehatan, melakukan kunjungan rumah, berperan aktif dan mampu menjadi pendorong bagi masyarakat untuk berperilaku hidup sehat. Kader dapat membantu memobilisasi sumber daya masyarakat, mengadvocasi masyarakat serta membangun kemampuan lokal.

Berdasarkan dari berbagai faktor yang mempengaruhi dalam pencegahan ISPA pada balita diperlukan informasi terkait dengan masalah penyakit tersebut dan memberikan pelatihan kepada masyarakat tentang terapi komplementer yang dapat diterapkan untuk pencegahan dan pengobatan alternatif ISPA pada balita. Melalui pemberdayaan kader kesehatan diharapkan dapat menjadi pendamping masyarakat khususnya kelompok Ibu secara berkesinambungan 
yang diharapkan adanya peningkatan perilaku sehat dan mandiri dalam upaya pencegahan penyakit ISPA pada keluarga.

Tujuan kegiatan pengabdian masyarakat ini meningkatkan pengetahuan, mendapatkan bimbingan dan keterampilan dan sikap dasar dalam upaya pencegahan penyakit ISPA pada Balita dengan menggunakan Terapi Komplementer, untuk menciptakan atau meningkatkan kemampuan hidup sehat pada masyarakat baik individu maupun kelompok untuk dapat memecahkan berbagai permasalahan yang terkait dengan peningkatan kesehatan dan pencegahan penyakit secara berkesinambungan.

Manfaat yang diperoleh untuk masyarakat dari kegiatan pengabdian kepada masyarakat ini peningkatan pengetahuan kader kesehatan tentang ISPA pada balita, upaya pencegahan dan pengobatan yang dapat dilakukan oleh Ibu di rumah, mendapatkan informasi dan edukasi pada kader dan kelompok Ibu melalui penyuluhan kesehatan mengenai penyakit ISPA pada balita, upaya pencegahan penyakit ISPA, dan penggunaan terapi komplementer untuk pengobatan alternatif ISPA. Mendapatkan pemeriksaan kesehatan umum pada balita, peningkatan keterampilan kader Kesehatan dan kelompok melalui pelatihan terapi komplementer berupa pelatihan Pijat Bayi Balita, ramuan herbal untuk mengobati ISPA.

\section{METODE PELAKSANAAN}

Metode pelaksanaan pengabdian pada masyarakat ini dilakukan dengan memberikan informasi/ edukasi kepada kader kesehatan tentang ISPA, upaya pencegahan ISPA dan Penggunaan terapi komplementer pada ISPA Edukasi dilakukan untuk memberikan pengetahuan dasar kader kesehatan dan kelompok Ibu tentang ISPA dan upaya pencegahan penyakit dan penggunaan terapi komplementer untuk pengobatan alternatif ISPA. Memberikan pelatihan tehnik pijat untuk membantu mengurangi gejala dan mengobati ISPA kepada kader kesehatan dan kelompok ibu. Memberikan penyuluhan dan simulasi tentang terapi herbal/ ramuan tradisional untuk mengatasi ISPA pada balita.

Metode pelaksanaan kegiatan pengabdian kepada masyarakat dilakukan dengan :

1. Melakukan survey lokasi kegiatan pengabdian masyarakat ke Lingkungan VIII Kelurahan Sunggal

2. Melakukan wawancara dan identifikasi masalah dengan mitra tentang kegiatan Posyandu Balita dan jumlah Balita di Lingkungan VIII Kelurahan Sunggal

3. Mempersiapkan kegiatan penyuluhan Kesehatan dengan mengatur jarak kursi untuk peserta penyuluhan kesehatan

4. Melakukan pendataan peserta kegiatan penyuluhan yang terdiri dari Kader Kesehatan dan kelompok ibu yang mempunyai balita di Lingkungan VIII Kelurahan Sunggal

5. Pemeriksaan kesehatan umum dengan melakukan Protokol Kesehatan seperti pengukuran suhu, pembagian masker dan memberikan hand sanitizer

6. Membagikan Kuesioner Pre tes kepada peserta kegiatan penyuluhan kesehatan, untuk menilai pengetahuan dasar peserta tentang Terapi Komplementer ISPA

7. Edukasi/ penyuluhan kesehatan kepada kader Kesehatan dan kelompok ibu tentang Terapi Komplementer

8. Memberikan edukasi dan simulasi tentang terapi pijat kepada kader kesehatan dibimbing oleh fasilitator/ narasumber

9. Pemberdayaan kader kesehatan dengan mengarahkan dengan mengajarkan kepada kelompok ibu tentang terapi pijat pada Balita ISPA 


\section{HASIL DAN PEMBAHASAN}

Pelaksanaan awal kegiatan direncanakan dengan berkordinasi dengan mitra kader Kesehatan Lingkungan VIII Kelurahan Sunggal untuk menentukan lokasi kegiatan dan mengundang peserta kegiatan yang terdiri dari kader kesehatan dan kelompok ibu yang memiliki balitas di wilayah Lingkungan VIII Kelurahan Sunggal. Jumlah peserta pengabdian kepada masyarakat 41 orang yang terdiri dari Kader Kesehatan dan kelompok ibu, target yang ditentukan sebelumnya yaitu Kelompok Ibu yang mempunyai balita dan terdaftar sebagai peserta posyandu balita. Kegiatan pengabdian kepada masyarakat dihadiri juga oleh Kepala Lingkungan VIII dan tokoh agama setempat.

Peserta kelompok ibu sebagian besar rentang usia 26-35 tahun (65,9\%) dan mayoritas dengan tingkat pendidikan SMA $(75,6 \%)$, kelompok ibu sebagian besar bersuku bangsa Jawa $(46,3 \%)$, dengan penghasilan rata-rata terbanyak $<2$ juta $(61 \%)$, mayoritas status menikah $(92,7 \%)$, dan pemanfaatan fasilitas kesehatan sebagian besar ke Bidan (48,8\%). Gambaran karakteristik peserta kegiatan pengabdian kepada masyarakat (Tabel 1).

Tabel 1. Distribusi Frekuensi Karakteristik Kelompok Ibu di Lingkungan VIII

Kelurahan Sunggal

\begin{tabular}{|c|c|c|}
\hline Karakteristik & Frekuensi & Persentase $(\%)$ \\
\hline \multicolumn{3}{|l|}{ Usia } \\
\hline - $\quad 26-35$ tahun & 27 & 65,9 \\
\hline - $\quad 36-45$ tahun & 9 & 22,0 \\
\hline 46-55 tahun & 5 & 12,1 \\
\hline \multicolumn{3}{|l|}{ Suku Bangsa } \\
\hline - Aceh & 8 & 19,5 \\
\hline - Jawa & 19 & 46,3 \\
\hline - $\quad$ Mandailing & 5 & 12,2 \\
\hline - Melayu & 6 & 14,6 \\
\hline Lain-lain & 4 & 9,7 \\
\hline \multicolumn{3}{|l|}{ Pendidikan } \\
\hline$-\quad S D$ & 2 & 4,9 \\
\hline - $\quad$ SMP & 6 & 14,6 \\
\hline - $\quad$ SMA & 31 & 75,6 \\
\hline - PT & 2 & 4,9 \\
\hline \multicolumn{3}{|l|}{ Penghasilan } \\
\hline$-\quad<2$ juta & 25 & 61,0 \\
\hline$-\quad 2-3$ juta & 5 & 12,2 \\
\hline$-\quad>3$ juta & 11 & 26,8 \\
\hline \multicolumn{3}{|l|}{ Status Pernikahan } \\
\hline - Menikah & 38 & 92,7 \\
\hline - Janda & 3 & 7,3 \\
\hline \multicolumn{3}{|l|}{ Pemanfaatan } \\
\hline \multicolumn{3}{|l|}{ Fasilitas } \\
\hline Kesehatan & 21 & 51,2 \\
\hline - Bidan/ & 15 & 36,6 \\
\hline Posyandu & 5 & 12,2 \\
\hline
\end{tabular}


Hasil kuesioner menunjukkan responden terbanyak berada pada rentang usia 26-35 tahun $(69,5 \%)$, yang merupakan masuk kedalam fase dewasa awal. Usia dewasa merupakan masa seseorang dianggap telah matur, baik secara fisiologis, psikologis, dan kognitif. Dewasa awal merupakan usia yang tepat dalam menganalisa dan menerima informasi. Secara kognitif, kebiasaan berpikir rasional meningkat pada usia dewasa awal dan tengah. Sehingga pada usia tersebut masih mudah menerima informasi dengan baik dibandingkan usia lebih dari kelompok usia lebih tua, dan keinginan untuk memperoleh informasi untuk menambah pengetahuan masih tinggi sehingga dapat menjadi pengaruh terhadap perawatan Kesehatan balita (Dewi Purnama Sari 2020).

Mayoritas responden adalah orang tua dengan pendidikan terakhir SMA yaitu sebanyak (75\%), berdasarkan penelitian yang dilakukan oleh Ratna Sarai, dkk (2019) tentang pengetahuan dalam penyediaan makanan diperoleh semakin tinggi tingkat Pendidikan seseorang, maka semakin mudah pula menerima informasi pengetahuan sehingga orang tua dapat memberikan pengasuhan yang baik dan menjaga kesehatan anaknya dengan baik. Menurut Notoatmojo (2012), pengetahuan atau kognitif merupakan factor penting untuk menentukan Tindakan seseorang (over behaviour). Dalam hal dipengaruhi dengan pengetahuan yang baik akan mendorong ibu untuk melakukan tindakan yang berguna untuk tumbuh kembang balitanya antara lain penimbangan berat badan, mendapatkan imunisasi, mendapatkan pemberian makanan tambahan (PMT), dan penyuluhan mengenai kesehatan di Posyandu.

Hasil penelitian ini diperoleh bahwa mayoritas suku jawa menggunakan terapi komplementer yaitu didapatkan sebanyak (46,3\%). Bagi masyarakat Jawa terapi komplementer atau obat tradisional sering disebut Jamu, baik dalam bentuk rajangan maupun bentuk serbuk siap seduh. Jamu merupakan ramuan tradisional sebagai salah satu upaya pengobatan yang telah dikenal luas dan dimanfaatkan oleh masyarakat dengan tujuan mengobati penyakit ringan, mencegah datangnya penyakit, menjaga ketahanan dan kesehatan tubuh (Faizah, dkk, 2019). Penelitian lain tentang terapi komplementer untuk mengatasi ISPA pada balita yang dilakukan di Tanah Karo, menyatakan masyarakat karo menggunakan pengobatan herbal dengan minuman jahe madu, campuran jeruk nipis dan kecap, terapi pijat, terapi sembur dan kombinasi dari beberapa jenis terapi herbal. Berdasarkan wawancara dari penelitian ini menyatakan bahwa masyarakat memilih terapi komplementer tersebut pada bayi yang ISPA adalah karena sudah dari nenek moyang dan turun temurun. (Lufthiani \& Tersania, 2016).

Masyarakat Kelurahan Sunggal Kecamatan Medan Sunggal rata-rata pendapatan perbulan yaitu kurang dari 2 juta sebanyak (61\%), dari hasil wawancara dengan masyarakat menyatakan lebih memilih pengobatan tradisional dari pada pengobatan medis, hal ini dikarenakan pengobatan tradisional atau terapi komplementer lebih murah dan bahan-bahan pengobatan mudah didapatkan sesuai dengan kemampuan dari finansial masyarakat. Masyarakat lebih memilih memanfaatkan fasilitas pelayanan Kesehatan kepada Bidan/ Posyandu sebanyak (51,2\%), sesuai dengan penelitian bahwa Bidan Desa merupakan penyampai informasi yang optimal bagi masyarakat pedesaan, sebagai sumber komunikator yang dapat dipercaya dan sangat membantu dalam proses penyebaran informasi kesehatan. (Prasanti, Fuady dan Indriani, 2018). 
Tabel 2. Distribusi Frekuensi Hasil Pre tes dan Post Tes Pengetahuan kader dan kelompok ibu tentang Penyakit Terapi Komplementer, di wilayah kerja

\begin{tabular}{lcc}
\multicolumn{3}{c}{ Lingkungan VIII Kelurahan Sunggal } \\
\hline $\begin{array}{l}\text { Komponen } \\
\text { Pengetahuan }\end{array}$ & $\mathbf{f}$ & $(\boldsymbol{\%})$ \\
\hline Pre Tes & & \\
1. Baik & 12 & 29,3 \\
2. Cukup & 29 & 70,7 \\
\hline Pos Tes & & \\
1. Baik & 31 & 75,6 \\
2. Cukup & 10 & 24,4 \\
\hline
\end{tabular}

Tabel 4.3. Hasil Uji Paired $T$-Tes terhadap Pre dan Post Tes Pengetahuan Kader dan Kelompok Ibu tentang Terapi Komplementer, di wilayah kerja Lingkungan VIII Kelurahan Sunggal

\begin{tabular}{cccc}
\hline Variabel & T-Hitung & Sig & Mean \\
\hline $\begin{array}{c}\text { Pengetahuan Pre test \& } \\
\text { Pengetahuan Post Test }\end{array}$ & 4.663 & 0,000 & 0,463 \\
\hline
\end{tabular}

Hasil dari penelitian ini didapatkan bahwa ada perubahan skor yang semakin meningkat. Sebelum diberikan pendidikan kesehatan pada masyarakat didapatkan kategori cukup diperoleh (70,7\%), dan pengetahuan dengan kategori baik diperoleh $(29,3 \%)$, dalam pelaksaan kegiatan pendidikan kesehatan kepada masyarakat tentang Terapi Komplementer akan didapatkan peningkatan pengetahuan dengan hasil kategori baik menjadi $(75,6 \%)$ dan pengetahuan dengan kategori cukup diperoleh $(24,4 \%)$. Salah satu strategi untuk meningkatkan pengetahuan adalah melalui pendidikan kesehatan, pendidikan kesehatan akan mempunyai efek yang baik apabila dalam prosesnya metode maupun media yang baik. Salah satu metode pendidikan kesehatan adalah tanya jawab. Ceramah adalah pidato yang disampaikan oleh seorang pembicara di depan sekelompok pendengar, metode ini baik untuk sarana yang berpendidikan tinggi maupun berpendidikan rendah (Notoatmojo, 2012).

Peningkatan pengetahuan pada kategori baik dapat disebabkan karena proses pendidikan kesehatan diberikan dengan metode ceramah hal ini sangat memungkinkan untuk terjadi interaksi dua arah dan merupakan metode yang ilmiah (Prakoso, 2015). Pelaksanaan kegiatan Pendidikan Kesehatan yang dilakukan kepada masyarakat dalam bentuk pemberian penyuluhan Kesehatan, simulasi dan penyebaran media berupa leaflet. Pada penelitian lain tentang Pengaruh Pendidikan Kesehatan dengan media poster terhadap pengetahuan manajemen hipertensi pada penderita hipertensi diperoleh mengalami peningkatan setelah diberikan perlakuan. Hal ini dibuktikan dengan hasil uji Independent T-Test yang menghasilkan nilai $\mathrm{p}=0,001(\mathrm{p}<0,05)$, yang menunjukkan bahwa pendidikan kesehatan dengan media poster lebih efektif meningkatkan pengetahuan manajemen hipertensi dibandingkan dengan pemberian pendidikan kesehatan tanpa poster. (Ulya, Iskandar dan Triasih, 2018). Hasil penelitian lain menyatakan bahwa didapatkan peningkatan rata-rata pengetahuan responden tentang penatalaksanaan hipertensi dari 8.56 menjadi 13.31. hal ini disebabkan karena informasi dapat membantu seseorang untuk memperoleh pengetahuan. (Nofia, V. R., Zaimy, S., \& Sebdarini, P. (2019). 
Penelitian ini didukung oleh hasil penelitian yang didapatkan bahwa hasil kegiatan menunjukkan perbedaan pengetahuan sebelum dan sesudah diberikan penyuluhan. Semua responden berada dalam kategori pengetahuan baik (100\%), sebelumnya sebagian besar siswa berpengetahuan kurang tentang TRIAD KRR yaitu $80 \%$, dan cukup 20\%. (Handayani, 2020)
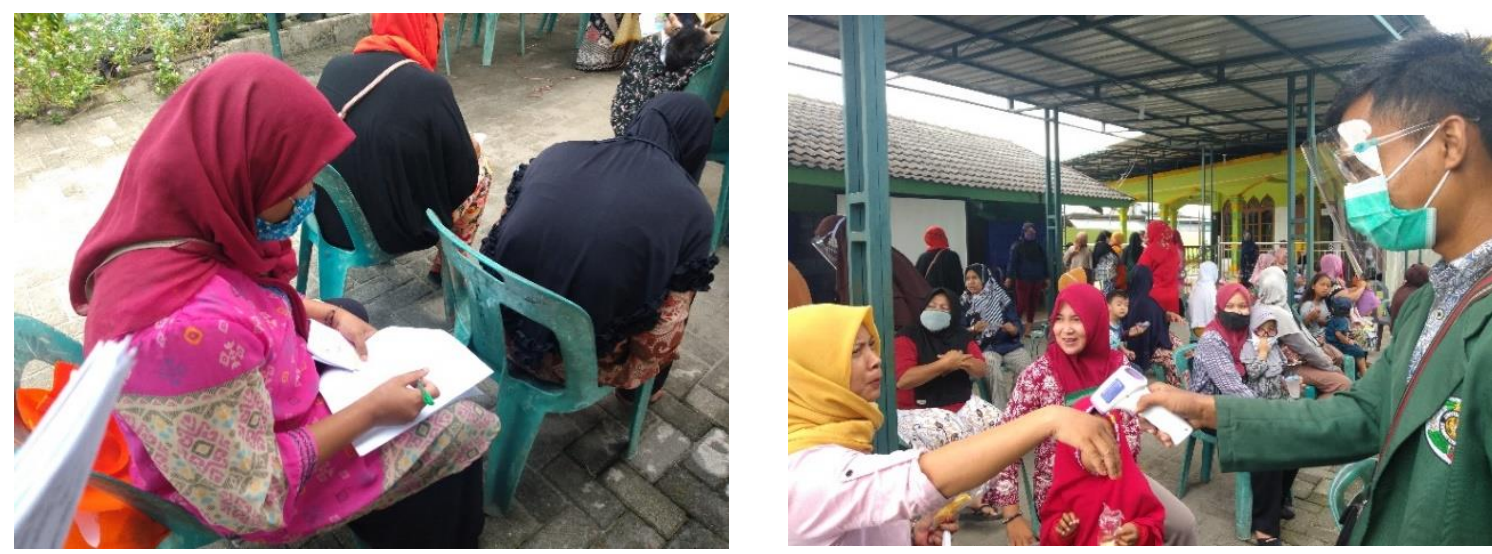

Gambar 1. Pelaksanaan Pre tes dan post tes, pemeriksaan protokol kesehatan dan edukasi

Kegiatan pemberdayaan kepada Kader Kesehatan dan Kelompok Ibu dilakukan dengan memberikan penyuluhan Kesehatan tentang Terapi Komplementer dan memberikan pelatihan dengan mengajarkan tentang terapi herbal dan pijat balita untuk mengatasi ISPA. Pelaksanaan awal kegiatan dilakukan dengan memberikan informasi melalui penyuluhan kesehatan, kegiatan ini bertujan untuk menyampaikan pesan, mengajak,memberikan pemikiran/solusi, menambah pengetahuan yang diperuntukan kepada masyarakat melalui penyebaran pesan agar dapat mempengaruhi perilaku yang lebih baik dan sehat kepada masyarakat.

Program pendampingan dilakukan kader Kesehatan kepada kelompok ibu pada kegiatan pengabdian kepada masyarakat ini dilakukan terlebih dahulu dengan mengadakan pelatihan tentang terapi komplementer yang meliputi terapi herbal untuk mengatasi ISPA pada anak dan simulasi terapi pijat pada Balita yang mengalami ISPA. Kegiatan pelatihan kader Kesehatan menjadi pendamping kelompok ibu dilakukan secara bersamaan yang diharapkan akan mempunyai persepsi dan pengetahuan yang sama tentang materi yang disampaikan. Hasil akhir dari kegiatan pengabdian kepada masyarakat ini diharapkan peran kader akan semakin nyata dapat menjadi pendamping kepada masyarakat khususnya kelompok ibu sebagai promotor atau penggerak Kesehatan melalui kegiatan Posyandu. 

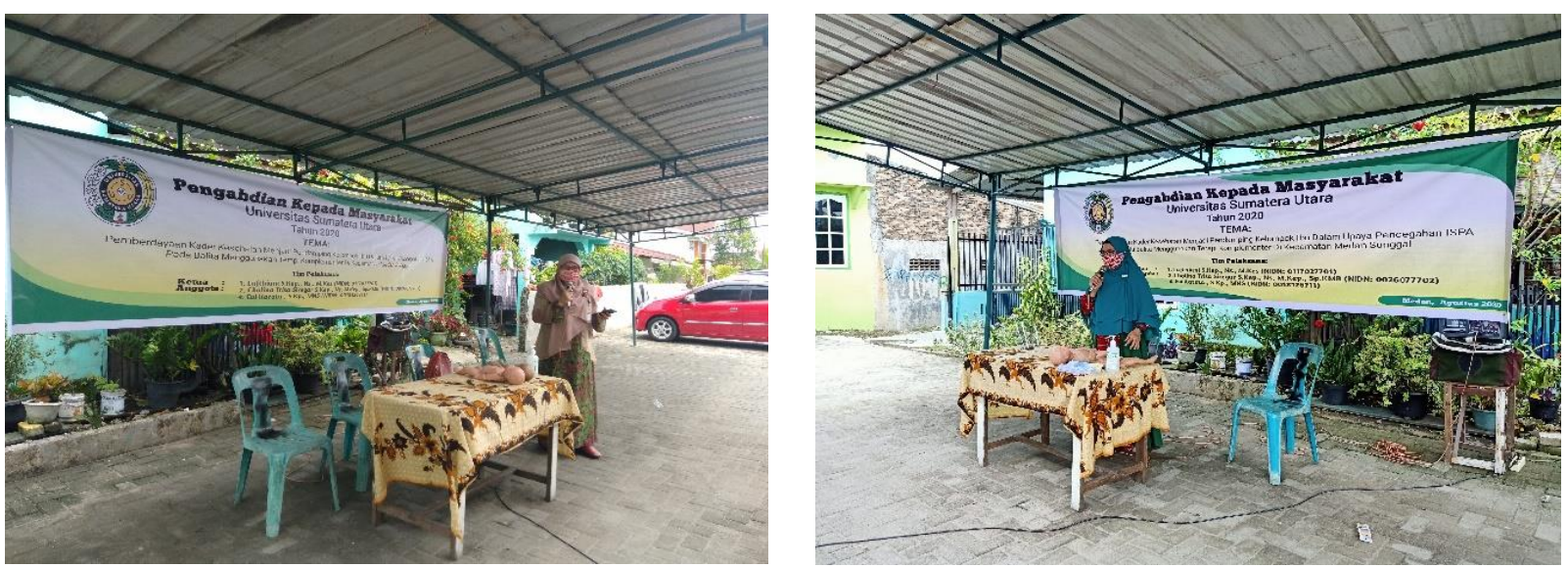

Gambar 2. Penyuluhan Kesehatan terapi komplementer, terapi herbal, pelatihan terapi pijat Balita ISPA
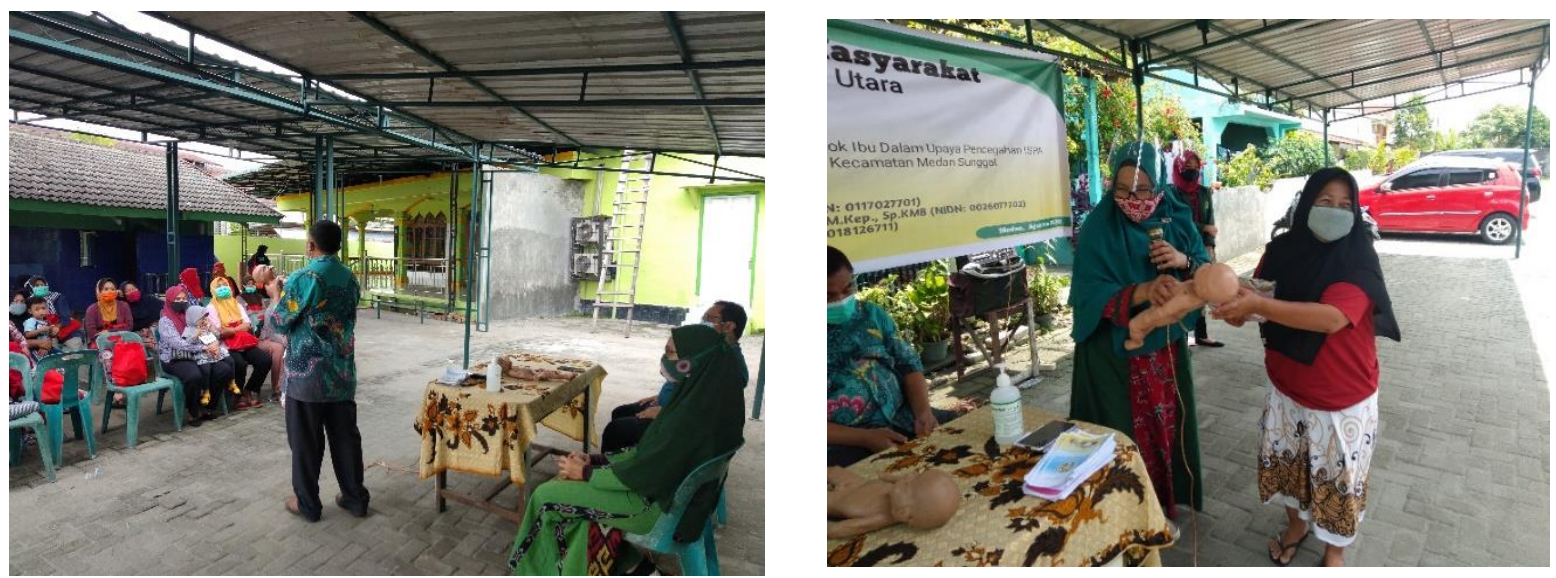

Gambar 3. Simulasi dan pendampingan terapi herbal dan pelatihan terapi pijat Balita ISPA

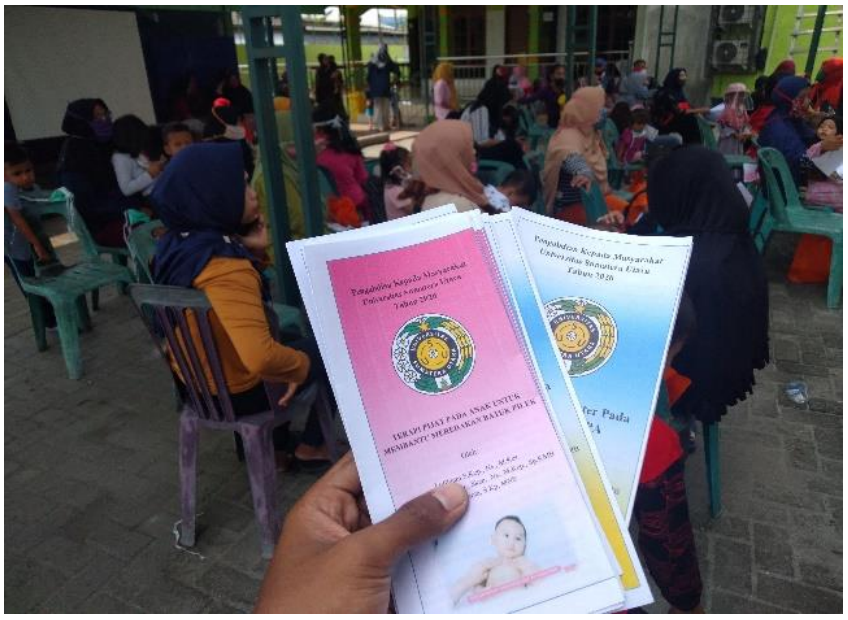



of ISPA in Toddlers by Using Complementary Therapy

Gambar 4. Media Pendidikan Kesehatan Leaflet Terapi Komplementer dan Terapi Pijat untuk Pencegahan ISPA pada Balita

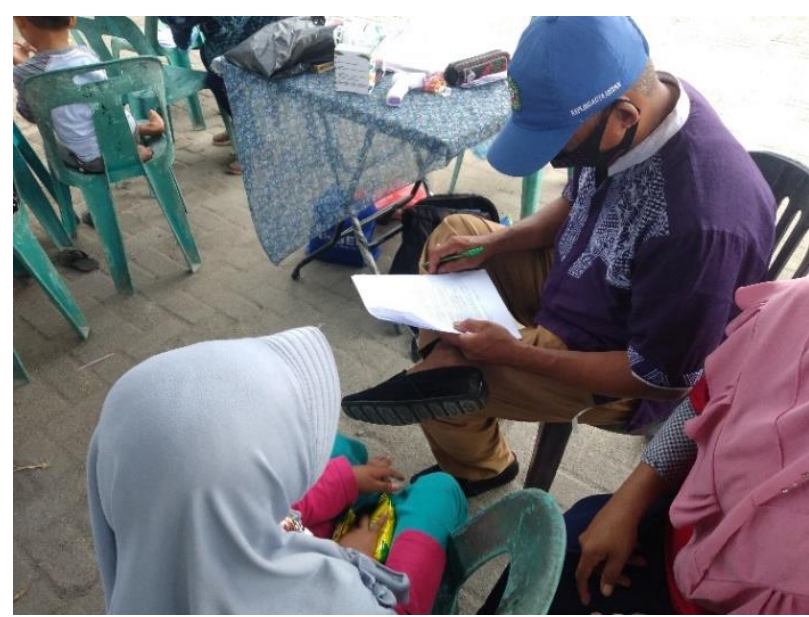

Gambar 5. Evaluasi Kegiatan/ Post tes

Partisipasi Mitra dalam pelaksanaan program ini adalah mencarikan informasi terkait dengan target dan kebutuhan dalam kegiatan. Informasi tersebut penting untuk menentukan besarnya anggaran yang diperlukan dalam pelaksanaan kegiatan. Selain itu mitra juga membantu mensosialisasikan program yang akan dilaksanakan pada kegiatan tersebut.

\section{KESIMPULAN}

Program pemberdayaan Kader Kesehatan menjadi Pendamping Kelompok Ibu dalam upaya pencegahan ISPA pada Balita menggunakan Terapi Komplementer yang dilaksanakan pada 41 orang kader dan kelompok ibu, memberikan hasil peningkatan pengetahuan dengan kategori baik, melalui kegiatan pengabdian kepada masyarakat ini meningkatkan keterampilan pada kader Kesehatan dan kelompok ibu melalui pendidikan kesehatan, pelatihan terapi herbal dan simulasi terapi pijat untuk mengatasi ISPA pada balita.

\section{UCAPAN TERIMA KASIH}

Tim pelaksana program pengabdian kepada masyarakat mengucapkan terima kasih kepada Lembaga Pengabdian Kepada Masyarakat USU yang telah mendanai kegiatan ini melalui Skim Dosen Wajib Mengabdi dengan sumber dana Non PNBP Universitas Sumatera Utara.

\section{DAFTAR PUSTAKA}

Dharmayanti, I., \& Tjandararini, D. H. (2018). Identifikasi indikator dalam indeks pembangunan kesehatan masyarakat (ipkm) untuk meningkatkan nilai sub-indeks penyakit menular. Jurnal Keperawatan Padjadjaran, 5(3).

Handayani, F. (2020). PENINGKATAN PENGETAHUAN SISWA SMA MUHAMMADIYAH TENTANG TIGA ANCAMAN DASAR KESEHATAN REPRODUKSI REMAJA (TRIAD KRR). Jurnal Pengabdian Masyarakat Kebidanan, 2(1), 9-17. Ulya, Z., Iskandar, A., \& Triasih, F. (2018). Pengaruh Pendidikan Kesehatan dengan Media Poster terhadap Pengetahuan Manajemen Hipertensi pada Penderita Hipertensi. Jurnal Keperawatan Soedirman, 12(1), 3846. 
Jayatmi, I., \& Imaniyah, E. (2019). Determinan Kejadian Infeksi Saluran Pernapasan Akut (ISPA) pada Balita. Jurnal Ilmiah Kebidanan Indonesia, 9(01), 18-25.

Kusumaningrum, A. P. D., Wijayanti, A. C., \& SKM, M. (2018). Hubungan Pemberian Asi Ekslusif, Berat Badan Lahir Dan Paparan Rokok Dengan Kejadian ISPA Pada Balita Di Wilayah Kerja Puskesmas Banyudono 1 (Doctoral dissertation, Universitas Muhammadiyah Surakarta).

Lembaga Pengambdian Kepada Masyarakat (LPKM). (2019). Panduan Penyusunan Proposal Pengabdian Kepada Masyarakat. Edisi 3. Universitas Sumatera Utara. https://simabdimas.usu.ac.id

Lufthiani, M., \& Tersania, A. (2016, November). Complementary Therapy in Handling ISPA in a Family that has Balita. In 1st International Conference on Social and Political Development (ICOSOP 2016). Atlantis Press.

Medan, D. K. (2016). Profil Kesehatan Kota Medan. Medan. Dinas Kesehatan Kota Medan. http://www.depkes.go.id

Nofia, V. R., Zaimy, S., \& Sebdarini, P. (2019). PENGARUH PENDIDIKAN KESEHATAN TENTANG PENATALAKSANAAN HIPERTENSI TERHADAPTINGKAT PENGETAHUANLANSIAHIPERTENSI DI WILAYAHKERJA PUSKESMASKUMUNDEBAI. Jurnal Abdimas Saintika, 1(1), 115-123.

PRAKOSO, D. Y. (2015). PENGARUH PENDIDIKAN KESEHATAN TENTANG PERSONAL HYGIENE DENGAN METODE CERAMAH DAN MEDIA AUDIOVISUAL TERHADAP PENGETAHUAN DAN SIKAP REMAJA PUTRI DALAM MENCEGAH KEPUTIHAN DI SMK BAKTI PURWOKERTO (Doctoral dissertation, UNIVERSITAS MUHAMMADIYAH PURWOKERTO).

Prasanti, D., Fuady, I., \& Indriani, S. S. (2018). OPTIMALISASI BIDAN DESA DALAM PENYEBARAN INFORMASI KESEHATAN BAGI MASYARAKAT DI KABUPATEN BANDUNG (Studi Kasus tentang Pemanfaatan Bidan Desa Dalam Penyebaran Informasi Kesehatan bagi Masyarakat di Kabupaten Bandung). Jurnal Komunikasi, 13(1), 81-92.

Rahman, A. N., Prabamurti, P. N., \& Riyanti, E. (2016). Faktor-faktor yang berhubungan dengan perilaku pencarian pelayanan kesehatan (health seeking behavior) pada santri di Pondok Pesantren Al Bisyri Tinjomoyo Semarang. Jurnal Kesehatan Masyarakat (e-Journal), 4(5), 246-258.

Tse, A. D. P., Suprojo, A., \& Adiwidjaja, I. (2017). Peran kader posyandu terhadap pembangunan kesehatan masyarakat. JISIP: Jurnal Ilmu Sosial Dan Ilmu Politik, 6(1).

Witdiawati, W., Sukmawati, S., \& Mamuroh, L. (2018). Penguatan Kapasitas Kader Kesehatan dalam Upaya Meningkatkan Dukungan Sosial Berbasis Masyarakat terhadap Klien Kanker Payudara. Media Karya Kesehatan, 1(1).

Yunita, L. (2016). Efektifitas Pendidikan Kesehatan Dengan Metode Ceramah Terhadap Tingkat Pengetahuan Ibu Dalam Penanganan Diare Balita di Sekitar UPT TPA Cipayung, Depok. 